\title{
First cytogenetic characterization of the sub-arctic marine fish Mallotus villosus (Müller, 1776), Osmeriformes, Osmeridae
}

\author{
Laura Ghigliotti ${ }^{1}$, Federico Mazzei ${ }^{1}$, Catherine Ozouf-Costaz ${ }^{2}$, Jørgen S. Christiansen ${ }^{3}$, \\ Svein-Erik Fevolden ${ }^{3}$ and Eva Pisano ${ }^{1}$ \\ ${ }^{I}$ Department of Biology, University of Genova, Genova, Italy. \\ ${ }^{2}$ Département Systématique et Evolution, Museum National d'Histoire Naturelle, Paris, France. \\ ${ }^{3}$ University of Tromsø, The Norwegian College of Fishery Science, Tromsø, Norway.
}

\begin{abstract}
The capelin, Mallotus villosus (Osmeriformes, Osmeridae), is an ecological and commercial key component of the sub-arctic ichthyofauna. Here, we provide the first cytogenetic information on the species based on both conventional karyotyping and chromosomal mapping of $45 \mathrm{~S}$ and $5 \mathrm{~S}$ ribosomal genes through fluorescence in situ hybridization (FISH). The capelin genome displayed a diploid number of 54 with the karyotypic formula $26 \mathrm{~m} / \mathrm{sm}+28 \mathrm{st} / \mathrm{a}$ and a fundamental number $(F N)=80$. Both classes of ribosomal genes appeared to be spread out to multiple chromosomal locations, i.e. the $45 S$ and $5 S$ rDNA clusters were detected on six and seven chromosome pairs, respectively. A linked chromosomal organization of the major and minor ribosomal genes classes has been visualized in most of the rDNAs chromosomal locations. A comparative analysis of the available cytogenetic data for the family Osmeridae reveals diploid numbers higher than 48 and high fundamental numbers. This suggests that a rearranged karyotype is a shared feature within this family.
\end{abstract}

Key words: capelin, chromosomes, Osmeridae, ribosomal genes.

Received: September 12, 2006; Accepted: April 19, 2007.

\section{Introduction}

The capelin, Mallotus villosus (Müller, 1776), is a smeltlike fish species widely distributed in sub-arctic waters (Gjøsæter, 1998). The monospecific genus Mallotus belongs to the family Osmeridae (sensu Johnson and Patterson, 1996). The precise position of Mallotus within the Osmeridae has been challenged, however. Johnson and Patterson (1996) included the genus within the tribe Salangini, whereas it appears to be closer related to the Osmerini/Hypomesinae clade according to a recent analysis of mitochondrial DNA sequences (Fu et al., 2005).

In the Barents Sea, capelin is an abundant component of the ichthyofauna. It is the main plankton-feeder and prey for Atlantic cod, Gadus morhua, and harp seal, Phoca groenlandica (Gjøsæter, 1998; Nilssen et al., 2000). The life cycle of Barents Sea capelin is characterized by extensive seasonal feeding and spawning migrations: juveniles and adults spend most of their life offshore and migrate towards the spawning grounds along the Norwegian and Russian coasts during sexual maturation in spring (Magnússon

Send correspondence to Laura Ghigliotti. Department of Biology, University of Genova, Viale Benedetto XV, 5, 16132 Genova, Italy. E-mail: pisano@unige.it. et al., 2005). The species appears to be semelparous (Gjøsæter and Loeng, 1987), although females from fjord populations may survive to spawn a second time (Christiansen and Siikavuopio, 1998). As the focal target of a major industrial fishery, the Barents Sea capelin has been extensively studied in terms of population dynamics, stock assessments, and management (e.g. Gjøsæter, 1998; Hjermann et al., 2004). Biological investigations have mainly focused on trophical ecology (Gjøsæter and Loeng, 1987; Gjøsæter, 1998), bioenergetics of reproduction (Christiansen and Siikavuopio, 1998; Karamushko and Christiansen, 2002), and on the swimming costs associated with spawning migrations (Behrens et al., 2006).

Despite the relevance of capelin in the ichthyofauna of the sub-arctic regions, several basic biological aspects, including cytogenetics, remain to be investigated. Actually, chromosomal studies on Arctic and sub-arctic fishes are surprisingly scanty (Klinkhardt et al., 1995; Ghigliotti et al., 2005), although cytogenetic data can provide valuable information on species diversification and diversity in fish communities (e.g. Galetti et al., 2006; Pisano et al., 2007b). Molecular cytogenetics allows resolution of the finer details of chromosome structure in terms of spatial arrangements of genes and DNA sequences. Some genomic 
regions such as the telomeric DNA, the centromeric satellites, and the ribosomal genes are largely recognized as powerful chromosomal markers for both inter-specific (e.g. Almeida-Toledo et al., 2002; Mazzei et al., 2004) and intra-specific (e.g. Gromicho and Collares-Pereira, 2004) analyses. In addition, recent advances in the field have largely increased the potential of fish cytogenetics in the study of genome organization and comparative genomics (Martins et al., 2004; Fischer et al., 2004; Phillips, 2007).

As a contribution to the biological and taxonomical knowledge of capelin, we have undertaken a cytogenetic study by using both conventional karyotyping and molecular cytogenetics. Here we provide the karyotype and the localization of $45 \mathrm{~S}$ (major or nucleolar) and $5 \mathrm{~S}$ (minor or extranucleolar) ribosomal genes through cytogenetic mapping. Apart from preliminary data presented as conference abstracts, no cytogenetic information is available for capelin.

\section{Materials and Methods}

\section{Animal sampling and chromosome preparation}

A total of 28 sexually mature capelin Mallotus villosus (14 males and 14 females) from the Barents Sea population were studied. Live specimens were sampled by bottom trawl from the R/V "Jan Mayen" along the Finnmark coast (Ingøy $7102^{\circ} \mathrm{N}, 2413^{\circ} \mathrm{E}$; Loppa $7029^{\circ} \mathrm{N}$, $2152^{\circ} \mathrm{E}$ ), northern Norway and transported to the research facilities at the University of Tromsø. The fish were kept in aquaria with running, aerated sea water. After treatment of specimens with colchicine, suspensions of mitotic cells were obtained from the head kidney and spleen following the method of Doussau de Bazignan and Ozouf-Costaz (1985) with slight modifications. Fixed chromosome preparations were stored at $-20^{\circ} \mathrm{C}$ for later analysis.

\section{Karyotyping}

Chromosome spreads were treated for conventional karyotyping after DAPI staining. Characterization of chromosomal morphology followed the standard nomenclature according to the centromeric position and arm ratio (Levan et al., 1964; Klinkhardt et al., 1995). The chromosomes were classified as metacentric (m), submetacentric (sm), subtelocentric (st) or acrocentric (a) and arranged in the karyotypes according to morphology and size.

\section{Ribosomal probes}

The $28 \mathrm{~S}$ probe for detecting the major ribosomal genes consisted of a 400 bp sequence containing the $\mathrm{C} 1$ and $\mathrm{C} 2$ conserved domains and a more divergent domain D1. The DNA fragment used as a probe for detecting the $5 \mathrm{~S}$ ribosomal genes is a $120 \mathrm{bp}$ sequence corresponding to the $5 \mathrm{~S}$ coding region (highly conserved among fishes and other vertebrates). The probes were prepared as previously described in Mazzei et al. (2004).
The $28 \mathrm{~S}$ and $5 \mathrm{~S}$ rDNA probes were labelled with biotin-16 dUTP and digoxigenin-11 dUTP respectively by use of a nick translation kit (Roche Diagnostics) following the manufacturer instruction. The labelled probes were purified by ethanol precipitation and dissolved individually or together in the hybridization buffer $(50 \%$ formamide/ $2 \times \mathrm{SSC}, 40 \mathrm{mM} \mathrm{KH}_{2} \mathrm{PO}_{4}, 10 \%$ dextran sulfate) to yield final concentrations of $10 \mathrm{ng} / \mu \mathrm{L}(28 \mathrm{~S} \mathrm{rDNA})$ and $20 \mathrm{ng} / \mu \mathrm{L}(5 \mathrm{~S}$ rDNA).

\section{Fluorescence in situ hybridization (FISH)}

One-color FISH and two-color FISH were performed as described previously (Mazzei et al., 2004). Briefly, the chromosomes were denatured by heating at $70{ }^{\circ} \mathrm{C}$ for $30 \mathrm{~s}$ in $70 \%(\mathrm{v} / \mathrm{v})$ formamide $/ 2 \times \mathrm{SSC}(\mathrm{pH} 7)$, dehydrated in a cold ethanol series, and air-dried. The probes were applied to chromosomal spreads ( $20 \mu \mathrm{L}$ per slide) and the slides were incubated overnight in a moist chamber at $37^{\circ} \mathrm{C}$. High-stringency post-hybridization washing was performed in $2 \times \mathrm{SSC}$ at $72{ }^{\circ} \mathrm{C}(5 \mathrm{~min})$ followed by $2 \mathrm{~min}$ in $1 \times \mathrm{PBD}$ (MP Biomedicals) at room temperature. Bound single probe was detected by incubation of chromosomal spreads with streptavidin-FITC (MP Biomedicals); fluorescence signals of two-color FISH were visualized by coapplication of the rhodamine-anti-digoxigenin antibody (Roche Diagnostics) and streptavidin-FITC (MP Biomedicals). The chromosomes were counterstained in $0.3 \mu \mathrm{g} / \mathrm{mL} \mathrm{DAPI} / 2 \times \mathrm{SSC}$ and mounted in a standard antifade solution (Vector).

\section{Microscopic analyses}

The metaphases were analyzed by an Olympus BX61 or a Zeiss Axiophot equipped with CCD cameras for digital imaging. Micrographs were processed either by Genus Software (Applied Imaging) or by Adobe Photoshop and Corel Photopaint image analysis softwares.

\section{Results}

The main results of karyotyping and molecular cytogenetic characterization are summarized in Figure 1. Chromosomal counts of multiple metaphase plates from all the specimens gave a consistent number of 54 elements. The corresponding karyotype was established by arranging the 27 pairs of homologous DAPI-stained chromosomes into two series: the meta/submetacentric series composed by 13 pairs of chromosomes and the subtelo/acrocentric series made up of 14 pairs of elements (Figure 1a). Chromosome pairs in each series were arranged according to their size. A certain morphological ambiguity, mostly due to the variability in the condensation of chromosomes in different plates, made it difficult to classify some elements as submetacentrics or acrocentrics. This morphological variability was observed for chromosome pairs 4,5 , and 6 , finally assigned as submetacentrics, and in the homologs of pair 17, 

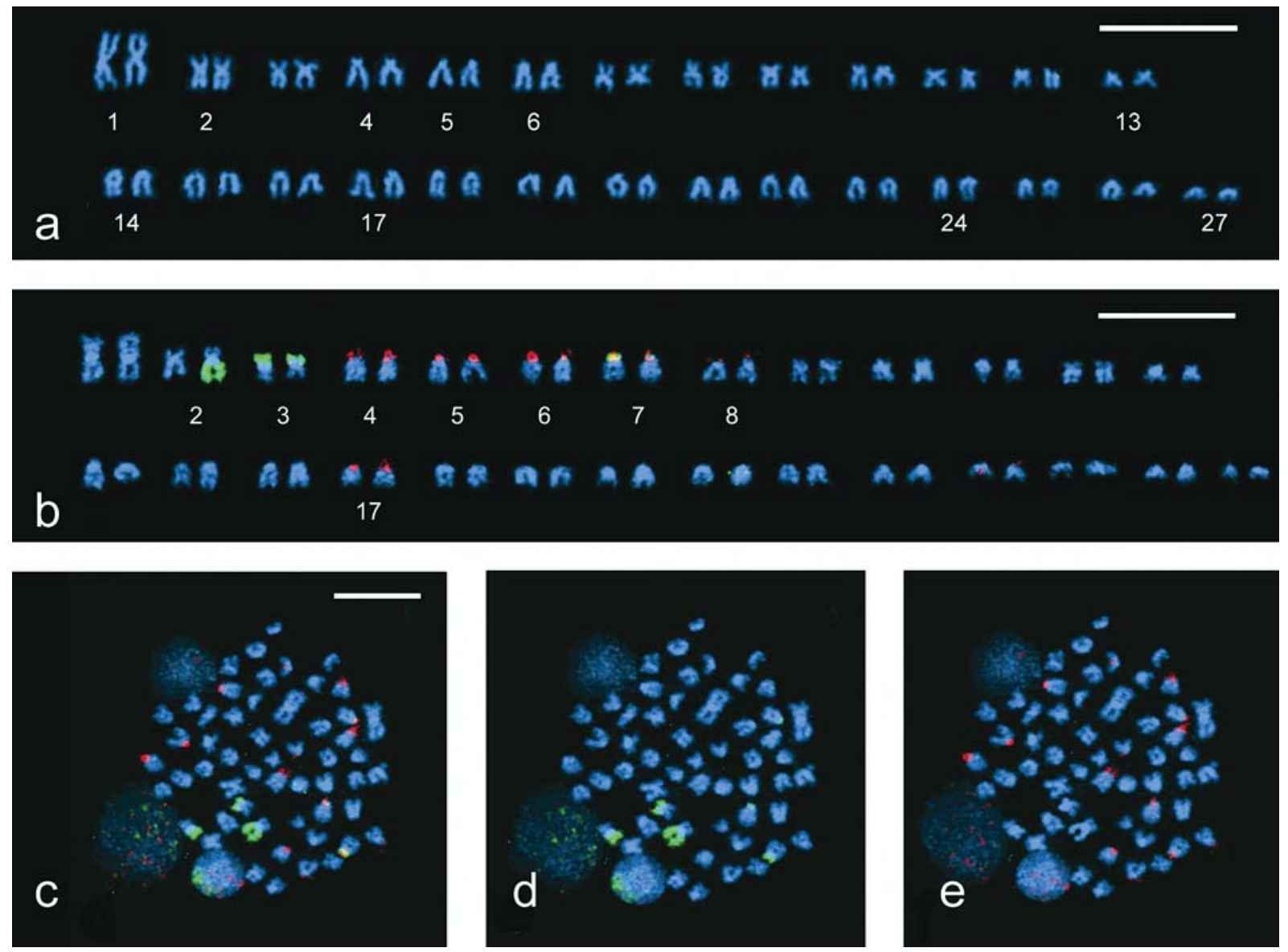

Figure 1 - Cytogenetics of the Barents Sea capelin Mallotus villosus. DAPI stained chromosomes arranged in the karyotype (a); pattern of 45S (green) and $5 \mathrm{~S}$ (red) ribosomal genes onto the karyotype after two-color FISH (b); simultaneous visualization of 45S and 5S rDNA loci onto metaphase chromosomes (c); separate visualization of major (d) and $5 \mathrm{~S}$ (e) ribosomal sequences on the same hybridized metaphase. Bars $=10 \mu \mathrm{m}$.

classified as acrocentrics. As a result, the karyotypic formula for capelin is $26 \mathrm{~m} / \mathrm{sm}+28 \mathrm{st} / \mathrm{a}$ and the fundamental number $(\mathrm{FN})$ is 80 . The chromosomes composing pair 1 were easily recognizable in all metaphases in being the largest elements of the set. The size of the chromosomes for this pair is at least twice the size of pair 2 and four times the size of the smallest elements of the karyotype (pair 27). Recognizable polymorphisms were not observed except for a size heteromorphism between the homologs of pairs 2 and 24 in some specimens.

The results of the in situ hybridization indicated that ribosomal genes are spread at several chromosomal locations (Figure 1b, c). The hybridization signals of the $28 \mathrm{~S}$ rDNA probe (Figure 1d) revealed that large amounts of major ribosomal gene clusters are located on the submetacentric chromosomes of pairs 2 and 3. On the homologs of pair 2, the ribosomal gene signals extend along the longest arms and, interestingly, they have consistently been detected in only one of the two chromosomes of the pair. On pair 3, the clusters of major ribosomal genes occupy the entire short arms of both the homologs. Minor amounts of major ribosomal genes were always detected on the short arms of the chromosomes composing pair 7. Small hybridization signals were also observed on the short arms of chromosomes number 4,5 , and 6 , in most of the metaphases. Hybridization signals of $5 \mathrm{~S}$ rDNA (Figure 1e) were detected on several chromosomes at the sub-centromeric position and extended along the small arms in the submetacentric elements. A differential intensity of the signals on the various chromosomes indicated that the $5 \mathrm{~S}$ ribosomal gene loci differ in number of repeated gene clusters. According to the intensity of the FISH signals, the bulk of 5S rDNA sequences is located on pairs 4, 5, 6, and 17 . Other loci, representing a minor number of $5 \mathrm{~S}$ genes, are located on chromosomes 7 and 8. For most of the locations, the 5S rDNA colocalized with the major rDNA, except for pairs 8 and 17. A small amount of 5S rDNA genes colocalized with the major ribosomal genes on the short arms of the chromosomes of pair 3 but, interestingly, 5S rDNA sequences were not detected on the chromosomes of pair 2, which are the elements bearing the largest amount of $45 \mathrm{~S}$ ribosomal genes in the complement.

No recognizable differences were noticed either in karyotypes or in the patterns of ribosomal genes between the studied males and females. 


\section{Discussion}

\section{The karyotype of capelin}

Among the 23,637 fish species of the division Teleostei (Nelson, 1994) only approximately 12\% have been cytotaxonomically studied (Klinkhardt et al., 1995). Thus, data are still insufficient to draw a general picture on the chromosome evolution in fishes. Nevertheless, by re-examining the available karyological data, Brum and Galetti (1997) proposed that the putative ancestral teleost karyotype of 48 acrocentrics (Ohno, 1974) should be restricted to the Euteleostei and Clupeomorpha. However, the hypothesis of Ohno (1974) was supported by Jaillon et al. (2004). These authors demonstrated that the entire genome duplication, which leads to a diploid number of 48 chromosomes, occurred in the ray-finned fish (actinopterygians) lineage after the separation from tetrapods.

The karyotype of capelin is composed of 54 chromosomes and appears slightly derived with respect to the possible ancestral set of 48 chromosomes. On the other hand, the high fundamental number (80), due to the occurrence of many biarmed elements, suggests that the present chromosomal morphology is the result of a complex history of rearrangements. The reconstruction of the steps that might lead to the present karyotype would require detailed comparative analyses among phylogenetically related species. Unfortunately, few cytogenetic data are available for the family Osmeridae, and they comprise mainly the basic characterization in four species from three genera (Hypomesus, Osmerus, and Sprinchus) (Table 1). The limited number of studied osmerid taxa doesn't provide sufficient data either to support hypotheses on chromosomal rearrangements that could have led to the present condition in capelin, or to reconstruct any karyotypic trend for the family. However, the occurrence of diploid numbers above 48 and high fundamental numbers in the four taxa studied (Ta- ble 1) suggest that species of the family Osmeridae are characterized by highly rearranged karyotypes.

\section{Chromosomal organization of ribosomal genes}

Ribosomal genes sequences (rRNA genes) have begun to play an important and innovating role as markers for karyotypic and chromosomal characterization for both freshwaters fishes (e.g. Vera et al., 2003; Hatanaka and Galetti, 2004; Kavalco et al., 2004; Mantovani et al., 2005) and, to a lesser degree, for marine species (Jankun et al., 2001; Pardo et al., 2001; Sola et al., 2003; Vitturi et al., 2005; Rossi et al., 2005; Galetti et al., 2006), including polar fishes (Mazzei et al., 2004). The chromosomal patterns of rRNA genes have been investigated in model and domestic fishes such as Tetraodon nigroviridis (Fischer et al., 2000), Oreochromis niloticus (Martins et al., 2000), Danio rerio (Phillips and Reed, 2000; Sola and Gornung, 2001), Xiphophorus maculatus (Ocalewicz, 2004), Oncorhynchus mykiss, and $O$. kisutch (Iturra et al., 2001). The repeated nature of both classes of ribosomal genes makes them easier to detected on the chromosomes by use of molecular cytogenetic techniques such as fluorescence in situ hybridization (FISH). According to the available data, the chromosomal patterns of ribosomal genes in fishes are much diversified. The rRNA gene clusters have been detected either in single or in multiple chromosomal locations (e.g., Sola et al., 2000; Almeida-Toledo et al., 2002), and the two classes of genes themselves have been found in linked or separate configurations (reviewed in Martins and Galetti, 2001; Martins, 2007). Inter-specific and intra-specific variability in the number of chromosomal loci has been described for both the major and minor ribosomal genes (Zhuo et al., 1995; Almeida-Toledo et al., 2002; Boron et al., 2006 among others). In some species the integration of cytogenetic mapping and sequence analyses provided important insights into the structure and organization of both 45S rDNA (e.g. Reed and Phillips, 2000) and 5S rDNA

Table 1 - Available cytogenetic information on species within the family Osmeridae.

\begin{tabular}{|c|c|c|c|c|c|}
\hline Species & $2 n$ & $\mathrm{FN}$ & Formula & $45 \mathrm{~S}$ rDNA* & $5 \mathrm{~S}$ rDNA* \\
\hline Mallotus villosus ${ }^{1}$ & 54 & 80 & $26 \mathrm{~m} / \mathrm{sm}+28 \mathrm{a}$ & 6 & 7 \\
\hline Hypomesus olidus ${ }^{2}$ & 56 & 78 & $22 \mathrm{~m} / \mathrm{sm}+34 \mathrm{st} / \mathrm{a}$ & & \\
\hline Hypomesus pretiosus ${ }^{3,4}$ & $\begin{array}{l}50 \\
52\end{array}$ & 60 & & & \\
\hline Hypomesus transpacificus ${ }^{5}$ & 56 & 82 & $26 \mathrm{sm}+30 \mathrm{a}$ & & \\
\hline Osmerus eperlanus ${ }^{6,7,8,9}$ & $\begin{array}{l}56 \\
54 \\
58 \\
56\end{array}$ & $\begin{array}{l}68 \\
70 \\
68 \\
70\end{array}$ & $\begin{array}{c}12 \mathrm{~m} / \mathrm{sm}+44 \mathrm{st} / \mathrm{a} \\
16 \mathrm{~m}+38 \mathrm{a} \\
10 \mathrm{~m}+48 \mathrm{a} \\
10 \mathrm{~m}+18 \mathrm{sm}+14 \mathrm{a}\end{array}$ & & \\
\hline Sprinchus starksi $i^{10,3}$ & $\begin{array}{l}50 \\
50\end{array}$ & 60 & & & \\
\hline
\end{tabular}

*Number of chromosome pairs bearing rDNA signals.

${ }^{1}$ Present study; ${ }^{2}$ Vasiliev, $1985 ;{ }^{3}$ Ohno, $1974 ;{ }^{4}$ Ohno et al., $1969 ;{ }^{5}$ Kitada et al., $1980 ;{ }^{6}$ Lajus, $1992 ;{ }^{7}$ Nygren et al., $1971 ;{ }^{8}$ Svärdson, $1945 ;{ }^{9}$ Ocalewicz et al., 2007; ${ }^{10}$ Ohno, 1970. 
(Martins and Galetti, 2001; Wasko et al., 2001), and has revealed the occurrence of sequence variants at different chromosomal loci. The cytogenetic and molecular data as a whole indicated that, despite overall evolutionary conservation, the organization of ribosomal genes in fishes is highly variable. This phenomenon has also been observed in a variety of organisms including other animals and plants (e.g. De Lucchini et al., 1997; Reed and Phillips, 2000; Pedrosa-Harand et al., 2006).

The present ribosomal gene mapping for the osmerid capelin indicated that both the major and the $5 \mathrm{~S}$ ribosomal genes are organized in multiple chromosomal loci, thus confirming the heterogeneous chromosomal organization of such sequences in fish species. A number of mechanisms has been proposed to explain the spread of rDNA sequences at various chromosomal locations as well as the origin of new rDNA loci (e.g. Reed and Phillips 2000; Pedrosa-Harand et al., 2006). Mechanisms mainly include structural chromosomal rearrangements such as translocations (e.g. Hayashi et al., 2001). However, the dispersion of rDNA repeats, either through intra-chromosomal recombination and insertion of circular intermediate DNA into a new locus (e.g. Dubcovski and Dvorak 1995; Martins, 2007), or by transposon mediated rDNA transfer (Schubert 1984; Raskina et al., 2004), has also been suggested. Changes in number and size of rDNA sites can also occur through ectopic recombination (interlocus unequal crossing over), especially when the rDNA sites are located in the chromosome terminal regions or close to other classes of repetitive DNA sequences. In capelin, rDNA signals indicate that most of the rDNA sequences are close to the centromeric regions: the contiguity of rDNA to the repetitive centromeric sequences may have enabled homologous recombination to take place between non-allelic sites, thus facilitating the distribution of ribosomal gene clusters to a large number of chromosomes.

To fully understand the pathways of ribosomal gene distribution on the chromosomes in capelin, comparable mapping data from other species of the family Osmeridae would be necessary. To our knowledge such data are presently lacking except for the species Osmerus eperlanus. Recent studies on this species indicated a single locus for the $45 \mathrm{~S}$ rDNA (indirectly detected through silver staining) and the spread of 5S rDNA on four chromosome pairs (Ocalewicz et al., 2007). Therefore, in the absence of more comprehensive data for phylogenetically related species, we can not assess the direction of the rDNAs spreading in the osmerid genome and explain the diversified rDNA chromosomal loci patterns. It would be interesting to examine, through complementary molecular analyses, if the multiple loci detected in capelin contain rDNA sequence variants.

A striking feature concerning the distribution of ribosomal genes in capelin is the detection of the larger cluster of major ribosomal genes in only one of the two homologs of pair 2, in all the specimens analyzed. It is well known that, owing to differences in the amount of cistrons, the homologous chromosomes bearing $45 \mathrm{~S}$ rDNA genes can exhibit size polymorphisms (e.g. Vinas et al., 1996; Mazzei et $a l ., 2004)$. In the light of the above evidence, our findings in capelin may be explained in terms of a strong heteromorphism of pair 2, which hampers detection of FISH signals in one of the two homologues when a very low amount of ribosomal gene sequences is present. Alternatively, the odd rDNA signal found in pair 2 could indicate a heterozygous condition of such genes, but this has to be investigated in depth through further analysis in a larger number of specimens.

The chromosomal linkage of the major and minor ribosomal genes classes, detected in most of the rDNAs locations in the capelin, is not in agreement with most observations in vertebrates, including fishes, where divergent locations of nucleolar and 5S rDNA have been reported (e.g. Martins and Galetti, 2001). Although the linkage between the two rRNA gene families is not functionally required, the growing literature on the topic suggests that such an association (at least at the chromosomal level) is more frequent than previously assumed: e.g. Salmoniformes (Fujiwara et al., 1998; Rossi and Gornung, 2005), Cypriniformes (Inafuku et al., 2000; Boron et al., 2006), Characiformes (Almeida-Toledo et al., 2002; Hatanaka and Galetti, 2004; Mantovani et al., 2005), and Perciformes (Mazzei at al., 2004). There is not enough information to answer whether the $5 \mathrm{~S}$ and major rDNA clusters are more efficient in linked or separated configurations, but we may speculate that possible functional interferences between too closely arranged $45 \mathrm{~S}$ and $5 \mathrm{~S}$ rDNA sequences (Martins and Galetti, 1999) could be compensated by increased amounts of clusters and/or by the spreading of sequences at multiple chromosome positions, as already suggested by Mazzei et al. (2004).

\section{Conclusions}

The present study provides the first basic chromosomal features of the ecologically and commercially important capelin. The karyologically derived chromosome set suggests a complex history of chromosome evolutionary changes in the family Osmeridae that would require comparable studies in related species to be understood. The interesting multiple location ribosomal pattern stresses the need to improve our knowledge of the organization on rDNA in the highly diversified teleostean lineages, including a better understanding of the mechanisms leading to the spread of rDNA sequences and the frequency of possible rDNA sequence variants. Further studies on the capelin and phylogenetically related species may give new insights to the evolution of rDNA in fishes, especially if cytogenetic studies are integrated with molecular sequence analyses. The combination of cytogenomic methods appears to be a particularly promising approach in fish cytogenetics and 
comparative genomics (Jaillon et al., 2004; Volff, 2005; Pisano et al., 2007b).

\section{Acknowledgments}

The research was supported by the Italian National Research Council (CNR), the University of Genoa, and the Norwegian Research Council (BASECOEX-Programme).

\section{References}

Almeida-Toledo LF, Ozouf-Costaz C, Foresti F, Bonillo C, Porto-Foresti F and Daniel-Silva MFZ (2002) Conservation of the 5S-bearing chromosome pair and co-localization with major rDNA clusters in five species of Astyanax (Pisces, Characidae). Cytogenet Genome Res 97:229-233.

Behrens JW, Præbel K and Steffensen JF (2006) Swimming energetics of the Barents Sea capelin (Mallotus villosus) during the spawning migration period. Exp Mar Biol Ecol 331:208-216.

Boron A, Ozouf-Costaz C, Coutanceau J-P and Woroniecka K (2006) Gene mapping of 28S and 5S rDNA sites in the spined loach Cobitis taenia (Pisces, Cobitidae) from a diploid population and a diploid - tetraploid population. Genetica 128:71-79.

Brum MJI and Galetti Jr P (1997) Teleostei ground plan karyotype. J Comp Biol 2:91-102.

Christiansen JS and Siikavuopio SI (1998) Survival and growth of post-spawning capelin (Mallotus villosus) - An introductory report from a laboratory study. In: Counc. Meet. of the Int. Counc. for the Exploration of the Sea. ICES, Copenhagen, CC 8:1-11.

De Lucchini S, Andronico F and Nardi I (1997) Molecular structure of the rDNA intergenic spacer (IGS) in Triturus: Implications for the hypervariability of rDNA loci. Chromosoma 106:315-326.

Doussau De Bazignan M and Ozouf-Costaz C (1985) Une technique rapide d'analyse chromosomique appliquée à sept espèces de poissons antarctiques. Cybium 9:5-74.

Dubcovsky J and Dvorak J (1995) Ribosomal RNA multigene loci: Nomads of the Triticeae genomes. Genetics 140:13671377.

Fischer C, Ozouf-Costaz C, Roest Crollius H, Dasilva C, Jaillon O, Bouneau L, Bonillo C, Weissenbach J and Bernot A (2000) Karyotype and chromosome location of characteristic tandem repeats in the pufferfish Tetraodon nigroviridis. Cytogenet Cell Genet 88:50-55.

Fischer C, Bouneau L, Coutanceau J-P, Weissenbach J, Volff J-N and Ozouf-Costaz C (2004) Global heterochromatic colocalization of transposable elements with minisatellites in the compact genome of the pufferfish Tetraodon nigroviridis. Gene 336:175-183.

Fu C, Luo J, Wu J, López JA, Zhong Y, Lei G and Chen J (2005) Phylogenetic relationships of salangid fishes (Osmeridae, Salanginae) with comments on phylogenetic placement of the salangids based on mitochondrial DNA sequences. Mol Phyl Evol 35:76-84.

Fujiwara A, Abe S, Yamaha E, Yamazaki F and Yoshida MC (1998) Chromosomal localization and heterochromatin association of ribosomal RNA gene loci and silver-stained nu- cleolar organizer regions in salmonid fishes. Chrom Res 6:463-471.

Galetti Jr PM, Molina WF, Affonso PRAM and Aguilar CT (2006) Assessing genetic diversity of Brazilian reef fishes by chromosomal and DNA markers. Genetica 126:161-177.

Ghigliotti L, Mazzei F, Christiansen JS, Fevolden S-E and Pisano E (2005) First cytogenetic analyses of the arctic fishes Boreogadus saida (polar cod) and Arctogadus glacialis (ice cod), family Gadidae. Polarnet Technical Report-1/2005:69-73. http://www2.polarnet.cnr.it/PTR/.

Gjøsæter H (1998) Population biology and exploitation of capelin (Mallotus villosus) in the Barents Sea. Sarsia 83:453-496.

Gjøsæter H and Loeng H (1987) Growth of the Barents Sea capelin, Mallotus villosus, in relation to climate. Environ Biol Fishes 20:293-300.

Gromicho M and Collares-Pereira MJ (2004) Polymorphism of major ribosomal gene chromosomal sites (NOR-phenotypes) in the hybridogenetic fish Squalius alburnoides complex (Cyprinidae) assessed through crossing experiments. Genetica 122:291-302.

Hatanaka T and Galetti PM (2004) Mapping of the 18S and 5S ribosomal RNA genes in the fish Prochilodus argenteus Agassiz, 1829 (Characiformes, Prochilodontidae). Genetica 122:239-244.

Hayasaki M, Morikawa T and Legget JM (2001) Intraspecific variation of $18 \mathrm{~S}-5,8 \mathrm{~S}-26 \mathrm{~S}$ rDNA sites revealed by FISH and RFLP in wild oat, Avena agadiriana. Genes Genet Syst 76:9-14.

Hjermann DØ, Ottersen G and Stenseth NC (2004) Competition among fishermen and fish causes the collapse of Barents Sea capelin. Proc Natl Acad Sci USA 101:11679-11684.

Inafuku J, Nabeyama M, Kikuma Y, Saitoh J, Kubota S and Kohno S (2000) Chromosomal location and nucleotide sequences of $5 \mathrm{~S}$ ribosomal DNA of two cyprinid species (Osteichthyes, Pisces). Chrom Res 8:193-199.

Iturra P, Lam N, de la Fuente M, Vergara N and Medrano JF (2001) Characterization of sex chromosomes in rainbow trout and coho salmon using fluorescence in situ hybridization (FISH). Genetica 111:125-131.

Jaillon O, Aury JM, Brunet F, Petit JL, Stange-Thomann N, Mauceli E, Bouneau L, Fischer C, Ozouf-Costaz C, Bernot A, et al. (2004) Genome duplication in the teleost fish Tetraodon nigroviridis reveals the early vertebrate protokaryotype. Nature 431:946-57.

Jankun M, Martinez P, Pardo BG, Kirtiklis L, Ráb P, Rábová M and Sanchez L (2001) Ribosomal genes in Coregonid fishes (Coregonus lavaretus, C. albula and C. peled) (Salmonidae): Single and multiple nucleolus organizer regions. Heredity 87:672-679.

Johnson GD and Patterson C (1996) Relationships of lower euteleostean fishes. In: Stiassny MLJ, Parenti LR and Johnson GD (eds) Interrelationships of Fishes. Academic Press, San Diego, pp 251-332.

Karamushko LI and Christiansen JS (2002) Aerobic scaling and resting metabolism in oviferous and post-spawning Barents Sea capelin Mallotus villosus villosus (Müller, 1776). Exp Mar Biol Ecol 269:1-8.

Kavalco KF, Pazza R, Bertollo LA and Moreira-Filho O (2004) Gene mapping of 5S rDNA sites in eight fish species from the Paraiba do Sul river basin, Brazil. Cytogenet Genome Res 106:107-110. 
Kitada J, Tatewaki R and Tagawa M (1980) Chromosomes of the pond smelt Hypomesus transpacificus nipponensis $\mathrm{M}$. Chrom Inform Serv 28:8-9.

Klinkhardt M, Tesche M and Greven H (1995) Database of fish chromosomes. Westarp-Wissenschaften, Magdeburg, 237 pp.

Lajus DL (1992) Chromosome sets of 13 fish species from the White Sea. In: Problems of Study, Rational Exploration and Conservation of Natural Resources of the White Sea. Petrozavodsk, pp 254-256 (in Russian).

Levan A, Fredga K and Sandberg AA (1964) Nomenclature for centromeric position on chromosome. Hereditas 52:201220.

Magnússon KG, Sigurdsson ST and Dereksdóttir EH (2005) A simulation model for capelin migrations in the North Atlantic. Nonlinear Anal-Real 6:747-771.

Mantovani M, Douglas L dos, Abel S and Moreira-Filho O (2005) Conserved $5 \mathrm{~S}$ and variable $45 \mathrm{~S}$ rDNA chromosomal localisation revealed by FISH in Astyanax scabripinnis (Pisces, Characidae). Genetica 123:211-216.

Martins C (2007) Chromosomes and repetitive DNAs: A contribution to the knowledge of the fish genome. In: Pisano E, Ozouf-Costaz C, Foresti F and Kapoor BG (eds) Fish Cytogenetics. Science Publishers Inc., Enfield, 502 pp.

Martins C and Galetti PM Jr (1999) Chromosomal localization of 5S rDNA genes in Leporinus fish (Anostomidae, Characiformes). Chrom Res 7:363-367.

Martins C and Galetti PM Jr (2001) Organization of 5S rDNA in species of the fish Leporinus: Two different genomic locations are characterized by distinct non transcribed spacers. Genome 44:903-910.

Martins C, Wasko AP, Oliveira C and Wright JM (2000) Nucleotide sequence of $5 \mathrm{~S}$ rDNA and localization of the ribosomal RNA genes to metaphase chromosomes of the Tilapiine cichlid fish, Oreochromis niloticus. Hereditas 133:39-46.

Martins C, Oliveira C, Wasko AP and Wright JM (2004) Physical mapping of the Nile tilapia (Oreochromis niloticus) genome by fluorescent in situ hybridization of repetitive DNAs to metaphase chromosomes - A review. Aquaculture 231:3749.

Mazzei F, Ghigliotti L, Bonillo C, Coutanceau J-P, Ozouf-Costaz $\mathrm{C}$ and Pisano E (2004) Chromosomal patterns of major and $5 \mathrm{~S}$ ribosomal DNA in six icefish species (Perciformes, Notothenioidei, Channichthyidae). Polar Biol 28:47-55.

Nelson J (1994) Fishes of the World. 3rd ed. John Wiley \& Sons Inc., New York, 600 pp.

Nilssen KT, Pettersen O-P, Folkow L and Haug T (2000) Food consumption estimates of Barents Sea harp seals. NAMMCO Sci Publ 2:9-27.

Nygren A, Nilsson B and Jahnke M (1971) Cytological studies in the smelt (Osmerus eperlanus L.). Hereditas 67:283-286.

Ocalewicz K (2004) Cytogenetic analysis of platyfish (Xiphophorus maculatus) shows location of major and minor rDNA on chromosomes. Hereditas 141:333-337.

Ocalewicz K, Hliwa P, Krol J, Rábová M, Stabinski R and Ráb P (2007) Karyotype and chromosomal characteristics of AgNOR sites and 5S rDNA in European smelt, Osmerus eperlanus. Genetica, DOI 10.1007/s10709-006-9110-9.

Ohno S (1970) The enormous diversity in genome sizes of fish as a reflection of nature's extensive experiments with gene duplication. Trans Amer Fish Soc 99:120-132.
Ohno S (1974) Protochordata, cyclostomata and pisces. In: John B (ed) Animal Cytogenetics, v. 4, Chordata I. Gerbruder Borntraeger, Berlin, pp 1-91.

Ohno S, Muramoto J, Klein J and Atkin NB (1969) Diploidtetraploid relationship in clupeoid and salmonid fishes of the Pacific. Chrom Today 2:139-147.

Pardo BG, Bouza C, Castro J, Martinez P and Sanchez L (2001) Localization of ribosomal genes in Pleuronectiformes using Ag-, CMA3-banding and in situ hybridization. Heredity 86:531-536

Pedrosa-Harand A, Souza de Almeida CC, Mosiolek M, Blair MW, Schweizer D and Guerra M (2006) Extensive ribosomal DNA amplification during Andean common bean (Phaseolus vulgaris L.) evolution. Theor Appl Genet 112:924-933.

Phillips RB (2007) Application of fluorescence in situ hybridization (FISH) to genome mapping in fishes. In: Pisano E, Ozouf-Costaz C, Foresti F and Kapoor BG (eds) Fish Cytogenetics. Science Publishers Inc., Enfield, 502 pp.

Phillips RB and Reed KM (2000) Localization of repetitive DNAs to zebrafish (Danio rerio) chromosomes by fluorescence in situ hybridization (FISH). Chrom Res 8:27-35.

Pisano E, Coscia MR, Mazzei F, Ghigliotti L, Coutanceau J-P, Ozouf-Costaz C and Oreste U (2007a) Cytogenetic mapping of Immunoglobulin heavy chain genes in Antarctic fish. Genetica, 130:9-17.

Pisano E, Ozouf-Costaz C, Foresti F and Kapoor BG (2007b) Fish Cytogenetics. Science Publishers Inc., Enfield, 502 pp.

Raskina O, Belayayev A and Nevo E (2004) Quantum speciation in Aegilops: Molecular cytogenetic evidence from rDNA cluster variability in natural population. Proc Natl Acad Sci USA 101:14818-14823.

Reed KM and Phillips RB (2000) Structure and organization of the rDNA intergenic spacer in lake trout (Salvelinus namaycush). Chrom Res 8:5-16.

Rossi AR and Gornung E (2005) Cytogenetic analysis of three Italian populations of Coregonus lavaretus (Pisces, Salmoniformes) with chromosomal localization of major and minor ribosomal genes, and telomeric repeats. Hereditas 142:15-21.

Rossi AR, Gornung E, Sola L and Nirchio M (2005) Comparative molecular cytogenetic analysis of two congeneric species, Mugil curema and M. liza (Pisces, Mugiliformes), characterized by significant karyotype diversity. Genetica 125:27-32.

Schubert I (1984) Mobile nucleolus organizing regions (NORs) in Allium (Liliaceae s. lat.)? Interferences from the specificity of silver staining. Plant Syst Evol 144:291-305.

Sola L and Gornung E (2001) Classical and molecular cytogenetics of the zebrafish, Danio rerio (Cyprinidae, Cypriniformes): An overview. Genetica 111:397-412.

Sola L, De Innocentis S, Gornung E, Papalia S, Rossi AR, Marino G, De Marco P and Cataudella (2000) Cytogenetic analysis of Epinephelus marginatus (Pisces, Serranidae) with the chromosome localization of $18 \mathrm{~S}$ and $5 \mathrm{~S}$ rRNA genes and of (TTAGGG)n telomeric sequences. Mar Biol 137:47-51.

Sola L, Rossi AR, Annesi F and Gornung E (2003) Cytogenetic studies in Sparus auratus (Pisces, Perciformes): Molecular organization of $5 \mathrm{~S}$ rDNA and chromosomal mapping of $5 \mathrm{~S}$ and $45 \mathrm{~S}$ ribosomal genes and of telomeric repeats. Hereditas 139:232-236. 
Svärdson G (1945) Chromosome studies on Salmonidae. Rep Swed State Inst Fresh-Water Fishery Res 23:1-151.

Vasiliev VP (1985) Evolutionary Karyology of Fishes. Nauka Press, Moscow, 300 pp (in Russian).

Vera MI, Molina A, Pinto R, Reyes M, Alvarez M, Krauskopf E, Quezada C, Torres J and Krauskopf M (2003) Genomic organization of the rDNA cistron of the teleost fish Cyprinus carpio. Biol Res 36:241-251.

Vinas A, Gomez C, Martinez P and Sanchez L (1996) Localization of rDNA genes in european eel (Anguilla anguilla) by FISH. Genome 39:1220-1223.
Vitturi R, Colomba M, Vizzini S, Libertini A, Barbieri R and Mazzola A (2005) Chromosomal location polymorphism of major rDNA sites in two Mediterranean populations of the killifish Aphanius fasciatus (Pisces, Cyprinodontidae). Micron 36:243-246.

Volff JN (2005) Genome evolution and biodiversity in teleost fish. Heredity 94:280-294.

Wasko AP, Martins C, Wright JM and Galetti Jr PM (2001) Molecular organization of $5 \mathrm{~S}$ rDNA in fishes of the genus Brycon. Genome 44:893-902.

Zhuo L, Reed KM and Phillips RB (1995) Hypervariability of ribosomal DNA at multiple chromosomal sites in lake trout (Salvelinus namaycush). Genome 38:487-497.

Associate Editor: Fausto Foresti

License information: This is an open-access article distributed under the terms of the Creative Commons Attribution License, which permits unrestricted use, distribution, and reproduction in any medium, provided the original work is properly cited. 